\section{Patterns of carbon allocation in a chronosequence of Caragana intermedia plantations in the Qinghai-Tibet Plateau}

\author{
Yun Tian ${ }^{(1-2)}$, Jixin Cao ${ }^{(3)}$, Xiaohui Yang ${ }^{(2)}$, Nan Shan ${ }^{(2)}$, Zhongjie Shi ${ }^{(2)}$
}

Revegetation is being considered as a mitigation option to improve the ecological environment and reduce the atmospheric carbon $(C)$ dioxide concentrations of regions experiencing desertification. This study assessed the development of the above- and belowground ecosystem $\mathrm{C}$ pools in a chronosequence of four Caragana intermedia plantations $(3,12,27$, and 37 years old) in the desertified region of the Qinghai-Tibet Plateau, China. The biomass C stock of the total shrub and under-canopy increased with stand age. The soil inorganic carbon (SIC) pool in the soil C stocks was approximately 3 to 7 times larger than the soil organic carbon (SOC) storage. Both SIC and SOC increased after revegetation. However, the contribution of SIC to the total ecosystem C stock decreased from $87 \%$ in the 3 -year-old plantation to $85 \%, 75 \%$, and $72 \%$ in the $12-$, 27-, and 37-year-old plantations, respectively. The total ecosystem C pool exhibited a greater increase in the shrub plantations than in the mobile dunes, but the total $\mathrm{C}$ stock of the stands changed slightly with time. Soil $\mathrm{C}$, including SOC and SIC, was the major contributor to the total ecosystem C stock for all shrub plantations. The aboveground shrub biomass became the secondary ecosystem $C$ pool in older srands. The results of this study indicate that revegetation in desertification ecosystems has a significant impact on SIC, SOC, and total ecosystem $C$ pools. Furthermore, the total ecosystem $C$ pool reached $a$ relatively stable state after sand-binding stands.

Keywords: Biomass Carbon, Shrub Plantation, Soil Organic Carbon, Soil Inorganic Carbon

\section{Introduction}

Arid and semi-arid regions cover more than one-third of the surface of the Earth, making these systems the most common types of biomes in the world (Reynolds 2001, Gao et al. 2012). The vegetation and soils in these regions represent approximately $46 \%$ of the global terrestrial carbon (C) stock (Verhoef et al. 1996, Lal 2002). Thus, arid and semiarid ecosystems play an integral role in the response of the global $\mathrm{C}$ cycle to climate change (Melillo et al. 1993, Housman et al. 2006, Lufafa et al. 2008). However, ecosystems in these areas are particularly vulnerable to environmental constraints and human activities (Puigdefábregas \& Mendizábal 1998, Gao et al. 2012). Previous studies showed that rising temperatures and shifting change will lead to the degeneration of community structures and functions in arid ecosystems (Ehleringer \& Cooper 1988, Midgley et al. 2004). Elevated atmospheric $\mathrm{CO}_{2}$ concentrations may cause the temperature of arid regions to increase sharply (Schlesinger et al. 1990, Maestre \& Cortina 2004). Areas affected by desertification have lost twothirds of their $\mathrm{C}$, mainly through the loss of vegetation and soil organic matter (IPCC 1996). precipitation patterns associated with climate

(1) Faculty of Soil and Water Conservation, Beijing Forestry University, 100083 Beijing (China); (2) Institute of Desertification Studies, Chinese Academy of Forestry, 100091 Beijing (China); (3) Key Laboratory of Forest Ecology and Environment, State Forestry Administration of China, Research Institute of Forest Ecology, Environment and Protection, Chinese Academy of Forestry, 100091 Beijing (China)

@ Xiaohui Yang (yangxhcaf@126.com)

Received: Dec 02, 2013 - Accepted: Dec 11, 2014

Citation: Tian Y, Cao J, Yang X, Shan N, Shi Z, 2015. Patterns of carbon allocation in a chronosequence of Caragana intermedia plantations in the Qinghai-Tibet Plateau. iForest 8: 756-764 [online 2015-04-08] URL: http://www.sisef.it/iforest/contents/?id=ifor1193-007

Communicated by: Giorgio Matteucci

Revegetation is one of the most effective methods for combating desertification and preventing soil $\mathrm{C}$ loss in arid and semi-arid regions (Yang \& Wu 2010, Amiraslani \& Dragovich 2011, Corona et al. 2012, D’Odorico et al. 2013). Shrub species are usually selected for revegetation, and they are therefore the dominant vegetation in such regions (Lufafa et al. 2009, Zhang et al. 2009, Conti et al. 2013). Many studies on the $C$ stock and allocation in shrub ecosystem of arid and semi-arid regions have been conducted on the Mediterranean coast, in Africa, and in Latin America (Farage et al. 2007, Trumper et al. 2008, Corona et al. 2012, RuizPeinado et al. 2013). Nevertheless, studies on this topic are scarce in China. China possesses $334000 \mathrm{~km}^{2}$ of desertified or desertification-prone lands, mainly in the north (Feng et al. 2000). Vegetation restoration, including revegetation using sand-binding species in desert regions to reduce the effects of desertification, has been applied to more than 2.4 million ha of degraded land in China (Li et al. 2004, 2007a, Zhang et al. 2009, Gao et al. 2012). Given the large distribution area, accurate and reliable estimates of $\mathrm{C}$ stock in the desertification regions are important in the development of effective policies and strategies to mitigate climate change.

A number of studies have shown that stand age may have a significant effect on the changes in $\mathrm{C}$ stock and allocation among different ecosystem components, such as trees, understory vegetation, forest floor, and mineral soil (Turner et al. 1995, Peichl \& Arain 2006, Peichl \& Arain 2007, Noh et al. 2010). Tree biomass and $C$ stock increase with stand age, and the allocation and growth rate of tree biomass and $\mathrm{C}$ pools vary across stands with different ages (Tobin \& Nieuwenhuis 2007, Li et al. 2011, Cao et al. 2012). This increasing trend can be described as sigmoidal, as commonly found in other studies (Hunt 1982), indicating that young forests grow rapidly up to a certain age and then gradually decrease their production. Most of the existing studies have focused on forest ecosystems, neglecting the importance of chronosequence in the $\mathrm{C}$ allocation of shrub plantations in desertified ecosystems. Caragana intermedia, which is highly adaptable to cold, dry, and sandy soils and has the capacity to form nitrogen-fixing nodules with rhizobia, is commonly planted to combat soil degeneration and stabilize sand dunes in the Qinghai-Tibet Plateau (Xu et al. 2007, Lu et al. 2009). We hypothesize that as stand age increasing, the $\mathrm{C}$ allocation of the $C$. intermedia ecosystem changes and the aboveground biomass contributes more C.

The objectives of this study were: (1) to quantify the main above- and belowground 


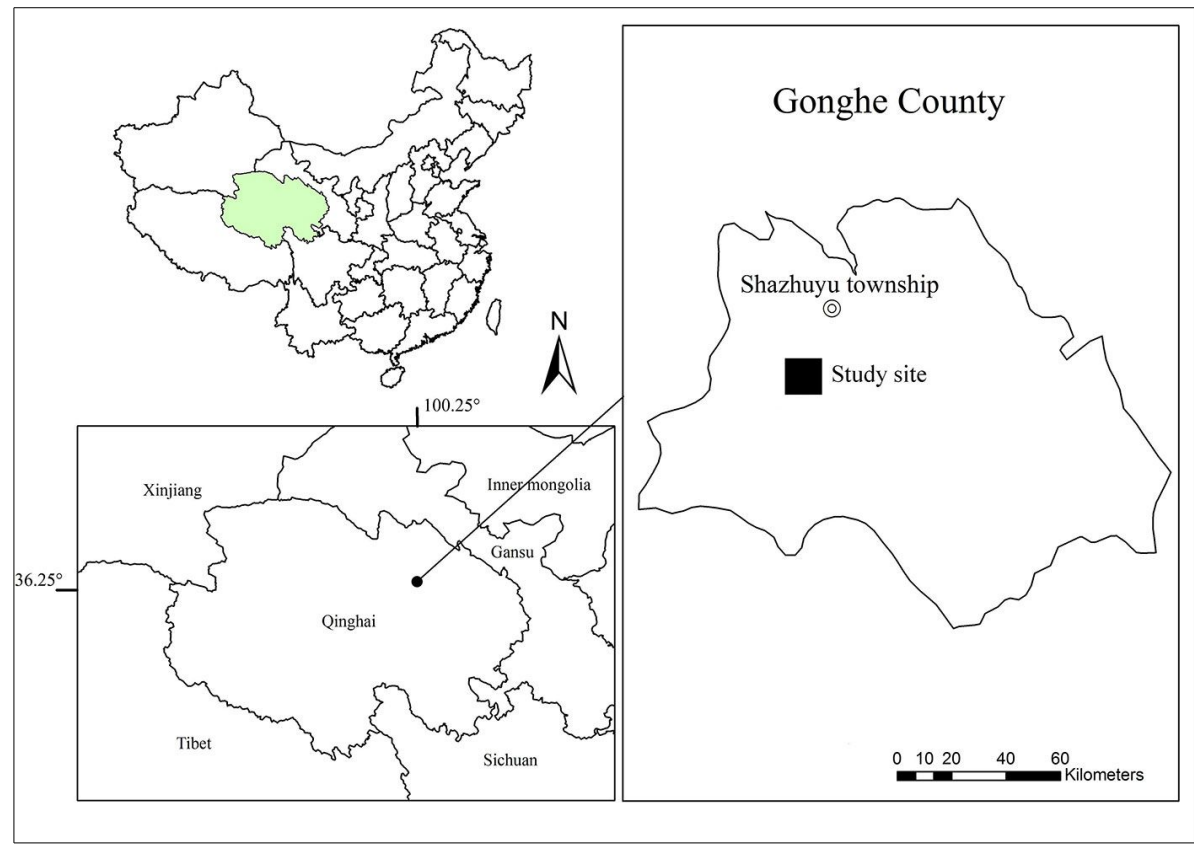

C pools across a chronosequence of four $C$. intermedia plantations $(3,12,27$, and 37 years old); and (2) to determine the changes in size and contribution of these $\mathrm{C}$ pools with stand age in the shrub plantation ecosystem. Estimating the changes in $\mathrm{C}$ stock and allocation among different ecosystem components with time is important to understand the contributions of revegetation to regions experiencing desertification and to the global $\mathrm{C}$ cycles. In addition, the contribution of soil inorganic carbon (SIC) to arid ecosystem $\mathrm{C}$ storage in China has not been well documented.

\section{Material and methods}

\section{Site description}

Our investigation was conducted in the Shazhuyu Township (Fig. 1), which is located in Gonghe Basin, Qinghai Province (China), where the mean daily temperature is
$-10{ }^{\circ} \mathrm{C}$ and $15.6^{\circ} \mathrm{C}$ in January and July, respectively. The mean annual precipitation is $246.3 \mathrm{~mm}$ (approximately $80 \%$ of the precipitation falls between May and September), and the annual potential evaporation is $1716.7 \mathrm{~mm}$. Average wind velocity is $2.7 \mathrm{~m}$ $\mathrm{s}^{-1}$, and the maximum wind velocity is $40 \mathrm{~m}$ $\mathrm{s}^{-1}$. The annual number of days with gale is approximately 30.6 days. Sand soil is contiguously distributed and forms many barchan chains, covering approximately 41955.7 $\mathrm{hm}^{2}$. In this place, the area of revegetation was approximately $100 \mathrm{hm}^{2}$ per year.

\section{Study design for plantation inventory}

Field measurements and sampling were conducted in July 2012, and consisted of a C. intermedia chronosequence that included 3-, 12-, 27-, and 37-year-old plantations. All 4 stands were established on the original mobile dune area and under similar environmental conditions (Tab. 1). All the stands of
Fig. 1 - The shrub plantation sampling locations in Shazhuyu township, Qinghai-Tibet Plateau (China).

Tab. 1 - Basic characteristics of the 3-, 12-, 27-, and 37-year-old Caragana intermedia stands.

\begin{tabular}{|c|c|c|c|c|c|c|c|c|c|c|}
\hline \multirow[b]{2}{*}{$\begin{array}{l}\text { Stand age } \\
\text { (years) }\end{array}$} & \multirow[b]{2}{*}{ 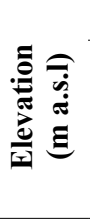 } & \multicolumn{6}{|c|}{ Basic properties of soil } & \multirow[b]{2}{*}{ 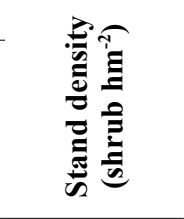 } & \multirow[b]{2}{*}{ 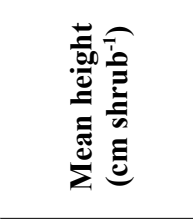 } & \multirow[b]{2}{*}{ Predominant native plants } \\
\hline & & 菅 & 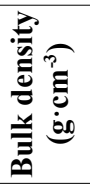 & 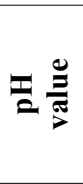 & 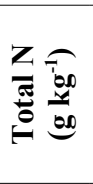 & 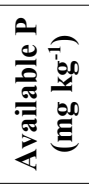 & 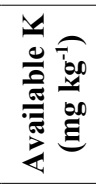 & & & \\
\hline $\begin{array}{l}\text { Mobile } \\
\text { dune }\end{array}$ & 2882 & Sandy soil & 1.52 & 8.78 & 0.09 & 2.9 & 51.2 & none & none & none \\
\hline 3 & 2880 & Sandy soil & 1.60 & 8.72 & 0.15 & 2.9 & 54.6 & $12767 \pm 441$ & $53.93 \pm 0.17$ & Corispermum lepidocarpum \\
\hline 12 & 2887 & Sandy soil & 1.56 & 8.55 & 0.33 & 3.1 & 72.7 & $5733 \pm 219$ & $96.07 \pm 1.81$ & Poa crymophila Keng \\
\hline 27 & 2873 & Sandy soil & 1.56 & 8.42 & 0.42 & 4.6 & 92.7 & $4367 \pm 333$ & $133.55 \pm 1.52$ & $\begin{array}{l}\text { Poa crymophila Keng, Potentilla chi- } \\
\text { nensis, Soil crust mosses Nostoc com- } \\
\text { mune }\end{array}$ \\
\hline 37 & 2881 & Sandy soil & 1.56 & 8.37 & 0.68 & 9.7 & 154.3 & $5033 \pm 260$ & $137.31 \pm 1.85$ & $\begin{array}{l}\text { Eragrostis pilosa, Poa crymophila } \\
\text { Keng, Potentilla chinensis, Soil crust } \\
\text { mosses Nostoc commune }\end{array}$ \\
\hline
\end{tabular}


Tab. 2 - Carbon concentration and C stock in shrub and undercanopy in the 3-, 12-, 27-, and 37-year-old Caragana intermedia plantations. (a): Data are presented as the mean value. Mean values of $\mathrm{C}$ stock within a row followed by different uppercase letters are significantly different among different stand ages $(\mathrm{p}<0.05)$. Mean values of $\mathrm{C}$ concentration within a row followed by different lowercase letters are signifi cantly different among different stand ages $(\mathrm{p}<0.05)$.

\begin{tabular}{|c|c|c|c|c|c|c|c|c|}
\hline \multirow[b]{2}{*}{ Component } & \multicolumn{2}{|c|}{ 3-year-old } & \multicolumn{2}{|c|}{ 12-year-old } & \multicolumn{2}{|c|}{ 27-year-old } & \multicolumn{2}{|c|}{ 37-year-old } \\
\hline & $\begin{array}{c}\mathrm{C} \\
(\%)\end{array}$ & 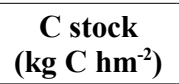 & $\begin{array}{c}\mathrm{C} \\
(\%)\end{array}$ & 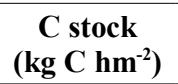 & $\begin{array}{c}\mathrm{C} \\
(\%)\end{array}$ & 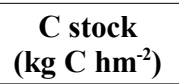 & $\begin{array}{c}\mathrm{C} \\
(\%)\end{array}$ & $\begin{array}{c}\text { C stock } \\
\left(\mathrm{kg} \mathrm{C} \mathrm{hm}^{-2}\right)\end{array}$ \\
\hline Total shrub & - & $1997.5^{\mathrm{C}}$ & - & $1943.6^{\mathrm{C}}$ & - & $7291.3^{\mathrm{B}}$ & - & $11864.7^{\mathrm{A}}$ \\
\hline Aboveground shrub & - & $1305.1^{\mathrm{C}}$ & - & $1512.3^{\mathrm{C}}$ & - & $5103.1^{\text {В }}$ & - & $8037.2^{\mathrm{A}}$ \\
\hline Foliage & $47.3^{\mathrm{a}}$ & $685.8^{\text {в }}$ & $42.0^{\mathrm{ab}}$ & $399.4^{\mathrm{C}}$ & $40.1^{\mathrm{ab}}$ & $719.1^{\text {в }}$ & $37.5^{b}$ & $1093.2^{\mathrm{A}}$ \\
\hline Fruit & - & - & $40.3^{b}$ & $61.9^{\mathrm{C}}$ & $43.6^{\mathrm{ab}}$ & $222.3^{\text {в }}$ & $47.5^{\mathrm{a}}$ & $257.4^{\mathrm{A}}$ \\
\hline Branch & $49.5^{\mathrm{a}}$ & $619.4^{\mathrm{C}}$ & $41.6^{\mathrm{b}}$ & $1051.0^{\mathrm{C}}$ & $48.1^{\mathrm{a}}$ & $4161.7^{\mathrm{B}}$ & $45.2^{\mathrm{ab}}$ & $6686.7^{\mathrm{A}}$ \\
\hline Root & $38.6^{\mathrm{ab}}$ & $692.4^{\mathrm{C}}$ & $35.9^{\mathrm{b}}$ & $431.4^{\mathrm{D}}$ & $44.9^{\mathrm{a}}$ & $2188.3^{\mathrm{B}}$ & $31.5^{\mathrm{b}}$ & $3827.5^{\mathrm{A}}$ \\
\hline Total undercanopy & - & $8.1^{\mathrm{C}}$ & - & $121.8^{\mathrm{C}}$ & - & $1437.5^{\text {В }}$ & - & $2407.7^{\mathrm{A}}$ \\
\hline Herb & $24.6^{\mathrm{ab}}$ & $6.7^{\text {в }}$ & $17.2^{\mathrm{b}}$ & $46.0^{\text {в }}$ & $34.3^{\mathrm{a}}$ & $153.3^{\text {в }}$ & $28.3^{\mathrm{ab}}$ & $1399.5^{\mathrm{A}}$ \\
\hline Nostoc commune & - & - & - & - & 17.6 & 36.7 & 18.5 & 99.5 \\
\hline Soil crust mosses & - & - & - & - & 18.4 & 1214.9 & 8.6 & 838.2 \\
\hline Litter & $11.2^{\mathrm{d}}$ & $1.3^{\mathrm{B}}$ & $30.5^{\mathrm{a}}$ & $75.8^{\mathrm{A}}$ & $22.3^{\mathrm{b}}$ & $32.6^{\mathrm{AB}}$ & $16.6^{\mathrm{c}}$ & $70.5^{\mathrm{A}}$ \\
\hline
\end{tabular}

biomass.

Three microplots $(1 \times 1 \mathrm{~m})$ were distributed within each plot for under-canopy investigation. In each microplot, all herbs, litter, and biological soil crusts were excavated. The biological soil crusts in the study site mainly comprised soil crust mosses, and only small amount of Nostoc commune were found. The herbs, biological soil crusts, and litter samples were oven dried at $65{ }^{\circ} \mathrm{C}$ for $48 \mathrm{~h}$ and weighed to determine the ratio of fresh weight to dry biomass. The dominant herb throughout the site was Poa crymophila Keng. We did not separate the herbs into species because of the small number of other species found. The herbs were also not separated into components because of their small root biomass.

C concentrations of all samples (shrubs, and under-canopy) were determined by the potassium dichromate oxidation method in the laboratory (Nelson \& Sommers 1982).

The dry biomass data of each shrub component and the aboveground, belowground, and total biomass per ha were calculated by using the age-specific allometric equations reported by Tian et al. (2014).

\section{Soil sampling}

Considering the possible fertile island effect, three replications of both under-canopy soil and inter-canopy soil were sampled in each plantation. Soil samples from mobile dunes were also collected in triplicate. In each soil sampling site, soil samples were taken at depths of 0 to $10 \mathrm{~cm}, 10$ to $20 \mathrm{~cm}$, 20 to $30 \mathrm{~cm}, 30$ to $50 \mathrm{~cm}, 50$ to $70 \mathrm{~cm}$, and 70 to $100 \mathrm{~cm}$. The basic properties of soil are listed in Tab. 1. All soil samples were air-dried and ground to pass through a $2 \mathrm{~mm}$ sieve. Soil mineral samples were also collected to obtain the corresponding bulk density of each depth by using a $500 \mathrm{~cm}^{3}$ soil ring, and they were subsequently oven dried at $105{ }^{\circ} \mathrm{C}$ to a constant weight. Soil organic carbon $(S O C)$ concentrations were determined using the potassium dichromate oxidation method (Nelson \& Sommers 1982), and SIC concentrations were measured by using the pressure-calcimeter method (Schenk \& Jackson 2002). The term mineral soil $C$ (SOC or SIC) stock refers to the $\mathrm{C}$ storage at a specified depth within a unit area and is calculated as follows (eqn. 1):

$$
\operatorname{SOC}(\operatorname{SIC})=\sum_{i=1}^{n} C_{i} \cdot \rho_{i} \cdot h_{i} \cdot\left(1-\theta_{i}\right) \cdot 100
$$

where $S O C$ or $S I C$ is the mineral soil organic/inorganic $\mathrm{C}$ stock $\left(\mathrm{kg} \mathrm{C} \mathrm{hm}^{-2}\right), C_{\mathrm{i}}$ is the C concentration $\left(\mathrm{g} \mathrm{kg}^{-1}\right), \rho_{\mathrm{i}}$ is the bulk density $\left(\mathrm{g} \mathrm{cm}^{-3}\right), h_{\mathrm{i}}$ is the thickness of the soil horizon $(\mathrm{cm})$, and $\theta_{\mathrm{i}}$ is the volumetric percentage of fragments $>2 \mathrm{~mm}$.

\section{Statistical analysis}

The statistical analysis of the data and the regression analysis for developing allometric equations were performed by using the SPSS ${ }^{\circledR}$ software package (ver. 18.0, SPSS, USA). The difference between the stand means and within-stand variations were exa- mined by one-way analysis of variance using ANOVA procedures.

\section{Results}

\section{Shrub biomass $C$ storage}

The $\mathrm{C}$ concentration of individual shrub components varied from $31.45 \%$ to $49.51 \%$ (Tab. 2). The lowest $\mathrm{C}$ concentration in each plantation except in the 27-year-old one was found in the root. The $\mathrm{C}$ concentration in the foliage of the shrubs decreased with plantation age contrary to the changes in the fruit. The relative share of $\mathrm{C}$ storage in the shrub biomass at each plantation is shown in Fig. 2. This result indicated the rapid increase of $\mathrm{C}$ concentrations from the 12-year-old to the 37-year-old plantation. $\mathrm{C}$ storage in the branch biomass represented $31 \%, 54 \%$, $57 \%$, and $56 \%$ of total shrub $\mathrm{C}$ in the $3-$, 12-, 27-, and 37-year-old plantations, respectively. Except for the 3-year-old plantation, the branches made the largest contribution to the total shrub C storage, followed by the roots. The contribution of foliage to total shrub C storage decreased from $34 \%$ in the 3 -year-old plantation to $21 \%, 10 \%$, and $9 \%$,

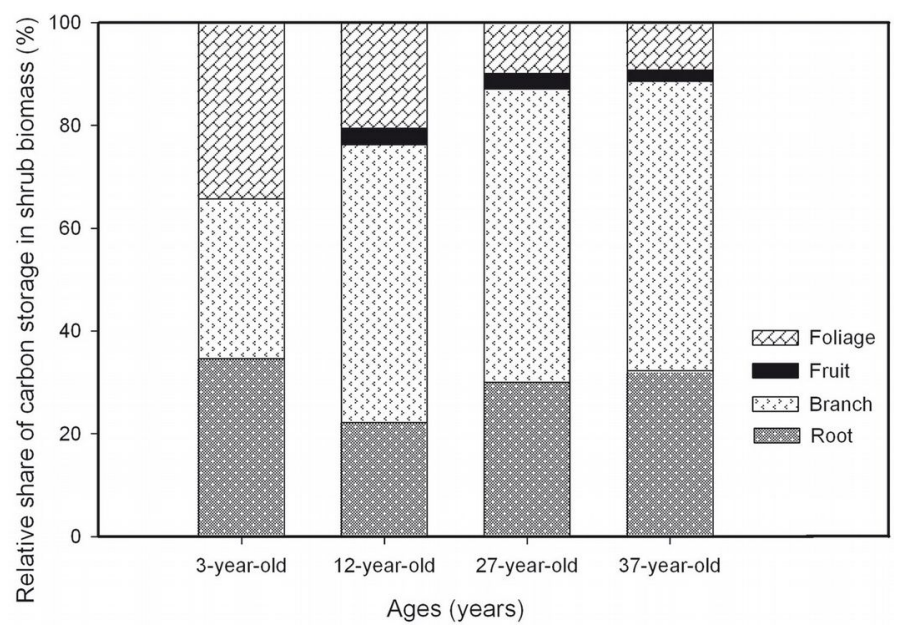

Fig. 2 - Relative share of carbon storage in shrub biomass in the 3-, 12-, 27-, and 37year-old Caragana intermedia plantations. 

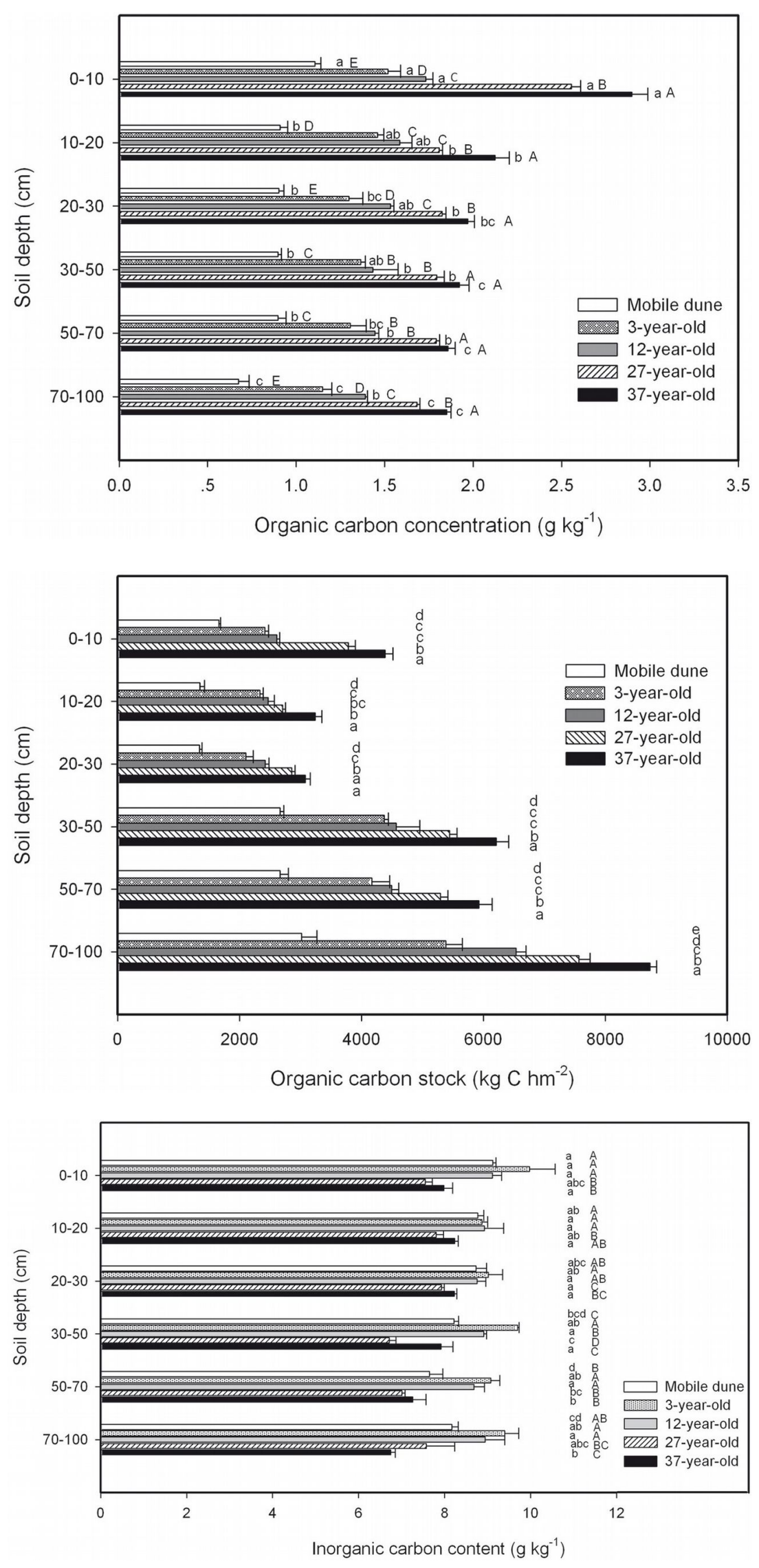

Fig. 3 - Soil organic $\mathrm{C}(S O C)$ concentration in samples taken at different soil depths in the 3-, 12-, 27-, and 37-year-old Caragana intermedia stands. Different uppercase letters indicate a significant difference between stand ages at the same horizon $(\mathrm{p}<0.05)$, different lowercase letters indicate a significant difference between different soil depths in the same stand $(\mathrm{p}<0.05)$. Error bars represent standard error (SE).

Fig. 4 - Soil organic $\mathrm{C}(S O C)$ stock at different soil depths in the 3-, 12-, 27-, and 37-year-old Caragana intermedia stands. Different capital letters indicate a significant difference between different stands at the same horizon $(\mathrm{p}<0.05)$. Error bars: SE.
Fig. 5 - Soil inorganic $\mathrm{C}(\mathrm{SIC})$ concentration in samples taken at different soil depths in the 3-, 12-, 27-, and 37-year-old Caragana intermedia stands. Different uppercase letters indicate a significant difference between stand ages at the same horizon $(\mathrm{p}<0.05)$, different lowercase letters indicate significant differences between different soil depths in the same stand $(p<0.05)$. Error bars: SE. 
Fig. 6 - Soil inorganic C (SIC) stock at different soil depths in the 3-, 12-, 27-, and 37-year-old Caragana intermedia stands. Different capital letters indicate significant differences between different stands at the same horizon $(p<0.05)$. Error bars: SE.

in 12-, 27-, and 37-year-old plantations, respectively. The $\mathrm{C}$ storage of the individual components of the shrub plantation in the 37-year-old stand was significantly larger than the $\mathrm{C}$ storage of the other stands.

\section{Under-canopy C storage}

Tab. 2 summarizes the under-canopy (herbs, biological soil crusts, and litter) $\mathrm{C}$ pools and individual $\mathrm{C}$ concentrations. The $\mathrm{C}$ concentration of the herbs ranged from $17 \%$ in the 12 -year-old stand to $34 \%$ in the 27-year-old stand. The $\mathrm{C}$ stock of the total under-canopy continuously increased with stand age. In the current study, biological soil crusts (soil crust mosses and Nostoc Commune) can be found in 27- and 37-yearold shrub plantations. The $\mathrm{C}$ concentration in the $N$. commune changed little, but it greatly decreased in soil crust mosses, from $18.35 \%$ in the 27 -year-old plantation to $8.64 \%$ in the 37 -year-old plantation. The C stored in the soil crust mosses of the 27- and 37 -year-old plantations accounted for $85 \%$ and $35 \%$, respectively, of the total undercanopy $\mathrm{C}$ pool.

The $\mathrm{C}$ concentration of the litter increased from $11 \%$ in the 3 -year-old plantation to approximately $30 \%$ in the 12 -year-old plantation and then decreased to $22 \%$ and $17 \%$ in the 27- and 37-year-old plantations, respectively. The $\mathrm{C}$ stock of the litter of the four shrub plantations followed the order of $12->$ 37- > 27- > 3-year-old plantation. No significant differences were found among the three older plantations.

\section{Mineral soil C storage}

$S O C$ concentration in the mineral soil at various depths for each plantation decreased with increasing soil depth, and it increased with plantation age (Fig. 3). The SOC concentrations in the four shrub plantations

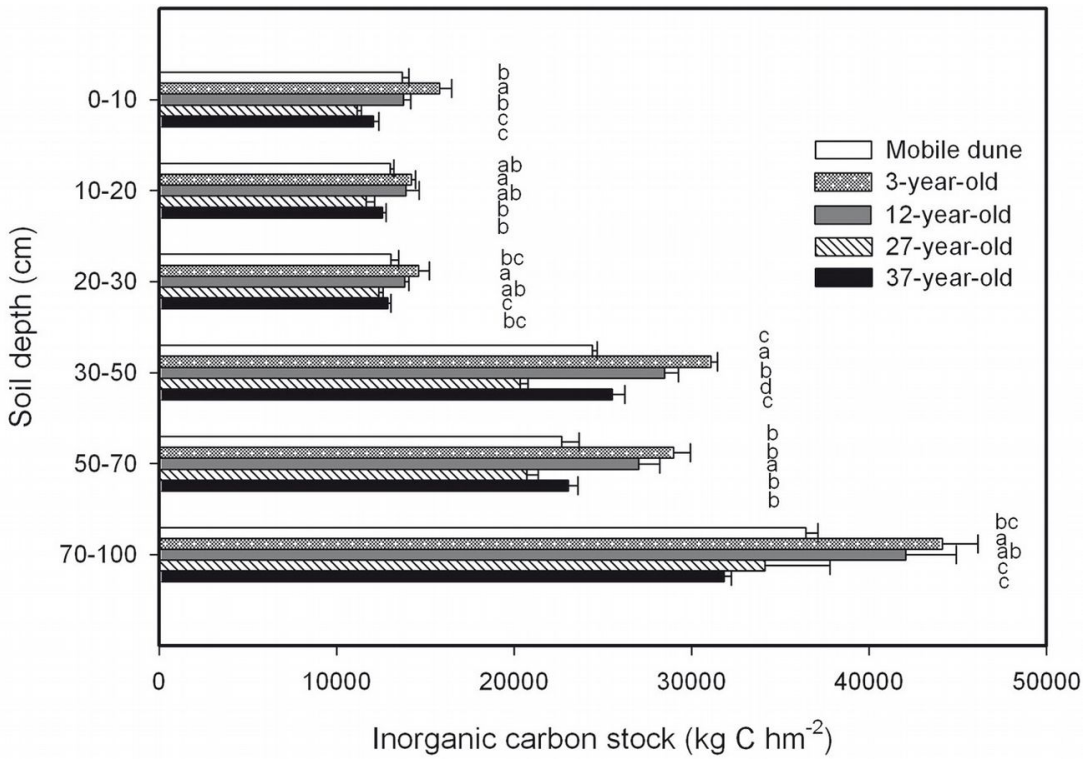

were significantly larger than in the mobile dune at the same soil depth. The total SOC stock across the six soil depths was 12 715.8, 20 793.4, 23 111.2, 27 652.9, and $31584.3 \mathrm{~kg} \mathrm{C} \mathrm{hm}^{-2}$ in the mobile dune, 3-, 12-, 27-, and 37-year-old plantations, respectively (Fig. 4). The $S O C$ stored in the whole soil profile $(0$ to $100 \mathrm{~cm})$ in the 37 -year-old plantation was approximately 2.5 times larger than the SOC stored in the mobile dune.

There were no significant differences in SIC concentration in the samples of the soil horizon taken at depths of $0 \mathrm{~cm}$ to $10 \mathrm{~cm}, 10$ $\mathrm{cm}$ to $20 \mathrm{~cm}, 20 \mathrm{~cm}$ to $30 \mathrm{~cm}, 30 \mathrm{~cm}$ to 50 $\mathrm{cm}, 50 \mathrm{~cm}$ to $70 \mathrm{~cm}$, and $70 \mathrm{~cm}$ to $100 \mathrm{~cm}$ across the entire chronosequence (Fig. 5). The total SIC stock across the six soil depths was 123.406.7, 148.900.6, 139.074.3, 110.476.9, and $117.978 .5 \mathrm{~kg} \mathrm{C} \mathrm{hm}^{-2}$ in the mobile dune, 3-, 12-, 27-, and 37-year-old plantations, respectively (Fig. 6). The ratio of SIC to SOC in the whole soil profile decreased from 10 in the mobile dune to 7,6 , 4 , and 4 in the 3-, 12-, 27-, and 37-year-old plantations, respectively. The contribution of total SIC stock in the total soil $\mathrm{C}$ stock (the sum of SIC and SOC) decreased from $91 \%$ in mobile dune to $88,86,80$, and $79 \%$ in the 3-, 12-, 27-, and 37-year-old plantations, respectively.

\section{Ecosystem C pools}

Tab. 3 summarizes the aboveground, belowground, and total ecosystem $\mathrm{C}$ stocks for the mobile dune and the four different-aged plantations. The $\mathrm{C}$ stocks of the aboveground, belowground, and total ecosystem in the 4 shrub plantations were larger than that in the mobile dune. However, the belowground C stock decreased from $170386.3 \mathrm{~kg}$

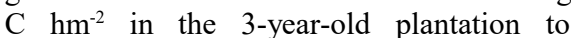
162616.3 and $140318.1 \mathrm{~kg} \mathrm{C} \mathrm{hm}^{-2}$ in the 12- and 27-year-old plantations, respectively, with a slight increase (153 $390.3 \mathrm{~kg} \mathrm{C}$ $\mathrm{hm}^{-2}$ ) in the 37-year-old plantation. Furthermore, the total ecosystem $\mathrm{C}$ stock decreased from $171699.5 \mathrm{~kg} \mathrm{C} \mathrm{hm}^{-2}$ in the 3-year-old plantation to 164250.9 and $146858.6 \mathrm{~kg} \mathrm{C}$ $\mathrm{hm}^{-2}$ in the 12- and 27-year-old plantations, respectively, with a slight increase (163 835.3 $\mathrm{kg} \mathrm{C} \mathrm{hm}^{-2}$ ) in the 37-year-old plantation.

The percentage contribution of the different $\mathrm{C}$ pool components within the shrub plantation ecosystem in the 3-, 12-, 27-, and 37 -year-old plantations are shown in Fig. 7. Mineral SIC and SOC were the two largest contributors to the total ecosystem C pool in all 4 plantations. SIC was the dominant $\mathrm{C}$ pool, accounting for $87 \%$ of the total ecosystem in the 3-year-old plantation. However,

Tab. 3 - Carbon stock of the aboveground, belowground, and total ecosystem in the mobile dune, 3-, 12-, 27-, and 37-year-old Caragana intermedia plantations $\left(\mathrm{kg} \mathrm{C} \mathrm{hm}^{-2}\right)$. Aboveground $\mathrm{C}$ pools included the $\mathrm{C}$ stored in aboveground shrub and the undercanopy; belowground $\mathrm{C}$ pools included the $\mathrm{C}$ stored in the shrub root and soil carbon (SOC and SIC). Data are presented as the mean value. Mean values within a row followed by different lowercase letters are significantly different in terms of $\mathrm{C}$ stock among different stands at $\mathrm{p}<0.05$.

\begin{tabular}{lcrrrr}
\hline Component & Mobile dune & 3-year-old & 12-year-old $^{\text {27-year-old }}$ & 37-year-old \\
\hline Aboveground & $0^{\mathrm{d}}$ & $1313.2^{\mathrm{c}}$ & $1634.0^{\mathrm{c}}$ & $6540.6^{\mathrm{b}}$ & $10444.9^{\mathrm{a}}$ \\
Belowground & $136122.4^{\mathrm{c}}$ & $170386.3^{\mathrm{a}}$ & $162616.9^{\mathrm{a}}$ & $140318.1^{\mathrm{c}}$ & $153390.3^{\mathrm{b}}$ \\
Total ecosystem & $136122.4^{\mathrm{c}}$ & $171699.5^{\mathrm{a}}$ & $164250.9^{\mathrm{a}}$ & $146858.6^{\mathrm{b}}$ & $163835.3^{\mathrm{a}}$ \\
\hline
\end{tabular}




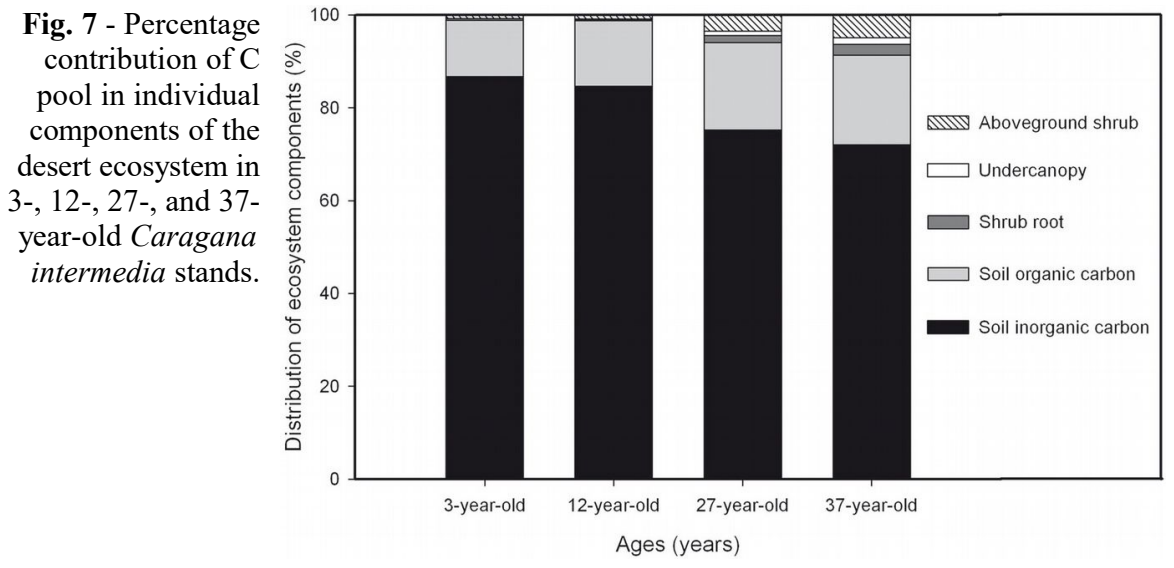

the contribution of SIC decreased to $85 \%$, $75 \%$ and $72 \%$ in the 12-, 27-, and 37-yearold plantations, respectively. The contribution of $S O C$ increased with plantation age from $12 \%$ in the 3 -year-old plantation to $19 \%$ in the 37 -year-old plantation. The contribution of aboveground shrub biomass $\mathrm{C}$ increased from $0.76 \%$ in the 3 -year-old plantation to $0.92 \%, 3.47 \%$, and $4.91 \%$ in the 12-, 27-, and 37-year-old plantations, respectively. The under-canopy contribution to the total ecosystem $\mathrm{C}$ pool increased slightly with plantation age. The contribution of the shrub root decreased from $0.40 \%$ in the 3 year-old plantation to $0.26 \%$ in the 12 -yearold plantation, and then increased to $1.49 \%$ and $2.34 \%$ in the 27 - and 37-year-old plantations, respectively.

\section{Discussion}

\section{Shrub biomass $C$ storage}

Goodale \& Davidson (2002) found that woody shrubs are a potentially large but poorly quantified $\mathrm{C}$ pool (uncertain pools) that contains large amounts of extra C. In plantations of $C$. intermedia in the desert of the Qinghai-Tibet Plateau, shrub biomass C stock increased with plantation age. This trend is commonly found in other tree studies (Taylor et al. 2007, Cao et al. 2012). The results of this chronosequence study suggest that age had a significant effect on shrub allometry and biomass $\mathrm{C}$ stock partitioning. The fact that the branches were the largest contributors in the $C$. intermedia plantations (except for the 3-year-old stand) might be attributed to the physiological characteristics of woody shrubs. The biomass $\mathrm{C}$ stock was similar for both 3- and 12-year-old plantations, but it increased by approximately 4 and 6 times in 27-year-old and 37year-old plantations. These results showed that younger shrub plantations had less biomass $\mathrm{C}$ stock than older shrub plantations.

The $\mathrm{C}$ concentrations of the vegetation components from the same species may be affected by the analysis, stand age, pedoclimatic conditions, and origin (Bert \& Danjon
2006). Previous studies have found that a constant value of $50 \% \mathrm{C}$ concentration may result in a significant error; thus, the use of a component-specific $\mathrm{C}$ concentration value to estimate the shrub biomass $\mathrm{C}$ pool is necessary ( $\mathrm{Li}$ et al. 2011). In the current study, the results clearly showed that the predicted $\mathrm{C}$ concentration of $50 \%$ for the shrub components was generally higher than the observed $\mathrm{C}$ concentration in the $C$. intermedia chronosequence. We found that the $\mathrm{C}$ concentration changed significantly in some individual shrub components across four different stand ages. Except for the $\mathrm{C}$ concentration of fruit biomass, the $\mathrm{C}$ concentrations of other components in the 37-year-old plantation were lower than those in the younger plantations (except for the branch $\mathrm{C}$ concentration in the 12-year-old plantation). The $\mathrm{C}$ concentrations in the roots had the lowest values compared with the other components (except in the 12-year-old plantation); this evidence was similar to previous results from other tree species (Li et al. 2011, Cao et al. 2012).

\section{Under-canopy C storage}

The $\mathrm{C}$ stock of the under-canopy increased with shrub plantation age. This trend might be caused by the increased biodiversity, which is related to ecosystem stability, in the sand-binding stands compared with moving dunes (Grime 1998, Tilman 1999, Li et al. 2004).

Previous studies have found that biological soil crusts can stabilize the topsoil (Xie et al. 2007, Su et al. 2012) and maintain and increase soil nutrients (Zaady et al. 2000, Belnap 2002, Su et al. 2013) while improving SOC accumulation ( $\mathrm{Li}$ et al. 2005, Wang et al. 2009, Su et al. 2012), serving as a vital C pool in dry land because of the considerable photosynthetic capacities of such crusts (Lange et al. 2007). In the present study, the C concentration in soil crust mosses strongly varied from the 27-year-old plantation to the 37 -year-old plantation. These results might be related to the stage of biological soil crusts development, canopy cover, photosynthetic capacity, and water condition ( $\mathrm{Su}$ et al.
2012, Whitton 2012).

In the present study, no pattern was found in the change of litter $\mathrm{C}$ pools over time, which is in accordance with previous findings from temperate forest ecosystems (Krause 1998, Peichl \& Arain 2006, Noh et al. 2010, Li et al. 2011). In contrast, other investigations found that the litter C stock increased with stand age (Pregizer \& Euskirchen 2004, Cao et al. 2014). Some previous reports have suggested that it is very difficult to detect patterns of change in litter organic matter using suitable sampling techniques due to the high spatial variation (Yanai et al. 2000, Johnson et al. 2003, Peichl \& Arain 2007, Taylor et al. 2007).

\section{Soil carbon}

In this study, the SIC stock was approximately three to seven times larger than the $S O C$ stock within the same stand. A similar result was observed in some previous reports (Schlesinger 1982, Eswaran et al. 2000, Batjes 2004, Lal 2004a). The increase in SOC stock with stand age might be due to the accumulation of organic matter in old shrub plantations. By contrast, the SIC stock decreased among the three younger plantations, and then increased slightly in the 37-yearold plantation. It has been suggested that most SICs in arid and semi-arid regions in China belong to the pedogenic carbonate class weathering of $\mathrm{Ca} / \mathrm{Mg}$-bearing silicates (Pan \& Guo 2000, Goddard et al. 2007, Wu et al. 2009). Thus, the large SIC storage in shrub plantations may be caused by the transfer process of atmospheric $\mathrm{CO}_{2}$ and soil C, i.e. (eqn. 2, eqn. 3):

$2 \mathrm{CO}_{2} \downarrow+3 \mathrm{H}_{2} \mathrm{O}+\mathrm{CaSiO}_{3} \rightarrow \mathrm{H}_{3} \mathrm{SiO}_{3}+2 \mathrm{HCO}_{3}^{-}+\mathrm{Ca}^{2+}$

$$
2 \mathrm{HCO}_{3}^{-}+\mathrm{Ca}^{2+} \rightarrow \mathrm{CaCO}_{3}+3 \mathrm{H}_{2} \mathrm{O}+\mathrm{CO}_{2} \uparrow
$$

(Adams 1993, Lal \& Kimble 2000, Mayorga 2008). The process of calcrete reservoir weathering consumes $2 \mathrm{~mol}$ of atmospheric $\mathrm{CO}_{2}$ for every mol released during the precipitation of pedogenic carbonate (Schlesinger 1982). The SIC content in 3- and 12-yearold plantations was higher than in the mobile dune; this result might be due to the artificial disturbance and the high holding capacity of shrub root systems for water from rainfall and groundwater (contain $\mathrm{CaCO}_{3}$ - Suarez 1977, Schenk \& Jackson 2002, Zhang et al. 2009, Wu et al. 2009). By contrast, the SIC content in 27- and 37-year-old plantations were less than that in the mobile dune; this might be caused by the transformation of considerable $S O C$ from $S I C$. This result was also the reason for the decrease in the SIC to $S O C$ ratio with plantation age. Although it is possible for the SOC to transform into SIC by the effect of temperature on the microcarbon cycle system " $\mathrm{SOC}-\mathrm{CO}_{2}-\mathrm{CaCO}_{3}$ " as $\mathrm{SOC}-\mathrm{CO}_{2}(\mathrm{~g})-\mathrm{CO}_{2}(\mathrm{aq})-\mathrm{HCO}_{3}^{-}(\mathrm{aq})-\mathrm{CaCO}_{3}(\mathrm{~s})$ (Pan \& Guo 2000, Goodale \& Davidson 
2002, Lal 2004b, Li et al. 2007b), the opposite process dominated the soil of this arid region after the revegetation.

\section{Ecosystem C pools}

Previous studies indicated that as the global climate becomes warmer, most types of soil are likely to become net sources of atmospheric $\mathrm{CO}_{2}$, because higher soil temperatures correspond to higher decomposition rates (Billings et al. 1983). However, revegetation may reduce those $C$ loss and even increase the ecosystem $\mathrm{C}$ sequestration (Schlesinger et al. 1990, Woodwell \& Machenzie 1995, Peichl \& Arain 2006, Cao et al. 2014). In the present study, the total ecosystem $\mathrm{C}$ stock in each of the four $C$. intermedia plantations was much higher than in the mobile dunes, indicating that the $C$. intermedia plantation has a considerable $\mathrm{C}$ sequestration ability. However, the total $\mathrm{C}$ stocks of the four aged stands changed slightly. Within the shrub plantation ecosystem, the aboveground $\mathrm{C}$ stock increased with stand age, whereas the belowground $\mathrm{C}$ stock decreased. The belowground $\mathrm{C}$ was the largest contributor to the total site $\mathrm{C}$ pool for each of the four stands. In contrast, some previous studies reported that the aboveground biomass $\mathrm{C}$ gradually becomes the largest contributor with stand age in the temperate forests (Peichl \& Arain 2006, Cao et al. 2012). Martin et al. (2005) found that the aboveground biomass $\mathrm{C}$ was always the largest contributor and the belowground $\mathrm{C}$ varied slightly in their chronosequence study of boreal mixedwood forest. These contradictory results might be due to differences in the rates of above- and belowground $\mathrm{C}$ accumulation among plant species with stand age. In the present study, the contribution of the biomass $C$ pool increased with stand age, however, but the $\mathrm{C}$ accumulation ability of $C$. intermedia was limited.

\section{Conclusions}

This study showed that $C$. intermedia chronosequence plantations have great potential to fix C. The total shrub biomass C, under-canopy biomass $\mathrm{C}$ and $S O C$ increased with stand age, whereas the underground $\mathrm{C}$ stock declined. The SIC and SOC were two major contributors to the total site $\mathrm{C}$ pool for all stand ages, but the total soil $\mathrm{C}$ slightly changed after revegetation because of the transfer of $\mathrm{SOC}-\mathrm{CO}_{2}-\mathrm{SIC}$. The information provided by this study will improve our understanding of $\mathrm{C}$ stock and the dynamic in C. intermedia chronosequence plantations. Furthermore, the results can be used in the $\mathrm{C}$ budget management of desertified ecosystems.

\section{Acknowledgments}

This study was supported by the fundamental research funds for the central universities
(NO.BLX2014-14), the grant under the national natural science fund (41130640) and (41271033) from National Natural Science Foundation of China, and forestry public welfare industry research (201204203) from State Forestry Bureau, P. R. China.

\section{References}

Adams JM (1993). Caliche and the carbon cycle. Nature 361: 213-214. - doi: 10.1038/361213b0 Amiraslani F, Dragovich D (2011). Combating desertification in Iran over the last 50 years: an overview of changing approaches. Journal of Environment management 92 (1): 1-13. - doi: 10.1016/j.jenvman.2010.08.012

Batjes NH (2004). Soil carbon stocks of Jordan and projected changes upon improved management of croplands. Geoderma 20: 40-47.

Belnap J (2002). Nitrogen fixation in biological soil crusts from southeast Utah, USA. Biology and Fertility of Soils 35: 128-135. - doi: 10.1007/s00374-002-0452-x

Bert D, Danjon F (2006). Carbon concentration variations in the roots, stem and crown of mature Pinus pinaster (Ait.). Forest Ecology and Management 222: 279-295. - doi: 10.1016/j.foreco.20 05.10.030

Billings WD, Luken JO, Mortensen DA, Peterson KM (1983). Increasing atmospheric carbon dioxide: possible effects on arctis tundra. Oecologia 58: 286-289. - doi: 10.1007/BF00385225

Cao J, Wang X, Tian Y, Wen Z, Zha T (2012). Pattern of carbon allocation across three different stages of stand development of a Chinese pine (Pinus tabulaeformis) forest. Ecological Research 27 (5): 883-892. - doi: 10.1007/s11284012-0965-1

Cao J, Tian Y, Zha T, Yang X, Wang X (2014). Carbon allocation dynamics across three different aged Platycladus orientalis (L.) Franco plantations. Forestry Chronicle 90 (2): 161-168. - doi: 10.5558/tfc2014-033

Conti G, Enrico L, Casanoves F, Díaz S (2013). Shrub biomass estimation in the semiarid Chaco Forest: a contribution to the quantification of an underrated carbon stock. Annals of Forest Science 70: 515-524. - doi: 10.1007/s13595-013-028 $5-9$

Corona P, Pasta S, Giardina G, La Mantia T (2012). Assessing the biomass of shrub tipical of Mediterranean pre-forest communities. Plant Biosystems 146 (2): 252-257. - doi: 10.1080/11 263504.2011.593200

D'Odorico P, Bhattachana A, Davis KF, Ravib S, Runyan CW (2013). Global desertification: drivers and feedbacks. Advances in Water Resources 51: 326-344. - doi: 10.1016/j.advwatres.20 12.01 .013

Ehleringer JR, Cooper TA (1988). Correlations between carbon isotope ratio and microhabitat in desert plants. Oecologia 76: 562-566. - doi: 10.1007/BF00397870

Eswaran H, Reich PF, Kimble JM, Beinroth FH, Padmanabhan E, Moncharoen P (2000). Global carbon stocks. In: "Global Change and Pedogenic Carbonate" (Lal R, Kimble JM, Eswaran
H, Stewart BA, Eds). CRC Press, Boca Raton, FL, USA, pp. 15-25.

Farage PK, Ardö J, Olsson L, Rienzi EA, Ball AS, Pretty JN (2007). The potential for soil carbon sequestration in three tropical dryland farming systems of Africa and Latin America: a modelling approach. Soil and Tillage Research 94: 457-472. - doi: 10.1016/j.still.2006.09.006

Feng Q, Cheng G, Endo K (2000). Carbon storage in desertified lands: a case study from North China. GeoJournal 51: 181-189. - doi: 10.1023/ A:1017557712431

Gao Y, Li X, Liu L, Jia R, Yang H, Li G, Wei Y (2012). Seasonal variation of carbon exchange from a revegetation area in a Chinese desert. Agricultural and Forest Meteorology 156: 134142. - doi: 10.1016/j.agrformet.2012.01.007 Goddard MA, Mikhailova EA, Post CJ, Schlautman MA (2007). Atmospheric $\mathrm{Mg}^{2+}$ wet deposition within the continental United States and implications for soil inorganic carbon sequestration. Tellus B 59 (1): 50-56. - doi: 10.1111/j.160 0-0889.2006.00242.x

Goodale CL, Davidson EA (2002). Uncertain sinks in the shrubs. Nature 418: 593-594. - doi: $10.1038 / 418593 a$

Grime JP (1998). Benefits of plant diversity to ecosystems: immediate, filter and founder effects. Ecology 86: 902-910. - doi: 10.1046/j.13 65-2745.1998.00306.x

Housman DC, Naumburg E, Huxman TE, Charlet TN, Nowak RS, Smith SD (2006). Increases in desert shrub productivity under elevated carbon dioxide vary with water availability. Ecosystems 9: 374-385. - doi: 10.1007/s10021-005-0124-4

Hunt R (1982). Plant growth curves. The functional approach to plant growth analysis. University Park Press, Baltimore, MD, USA, pp. 248. [online] URL: http://www.cabdirect.org/abstra cts/19840319829.html

IPCC (1996). Climate change 1995: the science of climate change. In: "Contribution of Working Group 1 to the Second Assessment Report of the Intergovernmental Panel on Climate Change." (Houghton JT, Meira Filho LG, Callander BA, Harris N, Kattenberg A, Maskell K eds). Cambridge University Press, Cambridge, UK, pp. 445-516.

Johnson DW, Todd Jr DE, Tolbert VR (2003). Chang ecosystem carbon and nitrogen in a loblolly pine plantation the first 18 years. Soil Science Society of America Journal 67: 15941601. - doi: 10.2136/sssaj2003.1594

Krause H (1998). Forest floor mass and nutrients in two chronosequences of plantations: jack pine vs. black spruce. Canadian Journal of Soil Science 78: 77-83. - doi: 10.4141/S97-029

Lal RJ, Kimble JM (2000). Pedogenic carbonates and the global carbon cycle. In: "Global Change and Pedogenic Carbonate" (Lal R, Kimble JM, Eswaran H, Stewart BA eds). CRC Press, Boca Raton, FL, USA, pp. 1-14.

Lal R (2002). Carbon sequestration in dryland ecosystems of west Asia and North Africa. Land Degradation and Development 13: 45-59. - doi: 10.1002/ldr.477 
Lal R (2004a). Soil carbon sequestration to mitigate climate change. Geoderma 234: 1-22. - doi: 10.1016/j.geoderma.2004.01.032

Lal R (2004b). Soil carbon sequestration impacts on global climate change and food security. Science 304: 1623-1627. - doi: 10.1126/science. 1097396

Lange OL, Green TGA, Meyer A (2007). Water relations and carbon dioxide exchange of epiphytic lichens in the Namib fog desert. Ecology of Plants 202: 479-487. - doi: 10.1016/j.flora.20 06.09 .006

Li X, Xiao H, Zhang J, Wang X (2004). Longterm ecosystem effects of sand-binding vegetation in the Tengger Desert, Northern China. Restoration Ecology 12 (3): 376-390. - doi: 10.1111/j.1061-2971.2004.00313.x

Li XR, Jia XH, Long LQ, Zerbe S (2005). Effects of biological soil crusts on seed bank, germination and establishment of two annual plant species in the Tengger Desert (N China). Plant and Soil 277: 375-385. - doi: 10.1007/s11104005-8162-4

Li X, Kong D, Tan H, Wang X (2007a). Changes in soil and vegetation following stabilization of dunes in the southeastern fringe of the Tengger Desert, China. Plant and Soil 300: 221-231. doi: 10.1007/s11104-007-9407-1

Li Z, Han F, Su Y, Zhang T, Sun B, Monts DL, Plodinec MJ (2007b). Assessment of soil organic and carbonate carbon storage in China. Geoderma 138: 119-126. - doi: 10.1016/j.geoderma. 2006.11.007

Li X, Yi MJ, Son Y, Park PS, Lee KH, Son YM, Kim RH, Jeong MJ (2011). Biomass and carbon storage in an age-sequence of Korea pine (Pinus koraiensis) plantation forests in central Korea. Journal of Plant Biology 54: 33-42. - doi: 10.1007/s12374-010-9140-9

Lufafa A, Diédhiou I, Sanba SAN, Séné M, Khouma M, Kizito F, Dick RP, Dossa E, Noller JS (2008). Carbon stocks and patterns in native shrub communities of Senegal's Peanut Basin. Geoderma 146: 75-82. - doi: 10.1016/j.geoder ma.2008.05.024

Lufafa A, Diédhiou I, Ndiaye NAS, Séné M, Kizito F, Dick RP, Noller JS (2009). Allometric relationships and peak-season community biomass stocks of native shrubs in Senegal's Peanut Basin. Jouynal of Arid Environments 73: 260266. - doi: 10.1016/j.jaridenv.2008.09.020

Lu Y, Chen W, Han L, Wang E, Chen W (2009). Rhizobium alkalisoli sp. nov., isolated from $\mathrm{Ca}$ ragana intermedia growing in saline-alkaline soils in the north of China. International Journal of Systematic and Evolutionary Microbiology 59: 3006-3011. - doi: 10.1099/ijs.0.007237-0

Maestre FT, Cortina J (2004). Do positive interactions increase with abiotic stress? A test from a semi-arid steppe. Proceedings of the Royal Society B - Biological Sciences 271: S331- S333. doi: 10.1098/rsbl.2004.0181

Martin JL, Gower ST, Plaut J, Holmes B (2005). Carbon pools in a boreal mixedwood logging chronosequence. Global Change Biology 11: 1883-1894. - doi: 10.1111/j.1365-2486.2005.01 019.x

Mayorga E (2008). Harvest of the century. Nature 451: 405-406. - doi: 10.1038/451405a

Melillo JM, McGuire AD, Kicklighter DW, Moore B, Vorosmarty CJ, Schloss AL (1993). Global climate change and terrestrial net primary production. Nature 363: 234-40. - doi: 10.1038/36 $3234 \mathrm{a} 0$

Midgley GF, Aranibar JN, Mantalana KB, Macko S (2004). Photosynthetic and gas exchange characteristics of dominant woody plants on a moisture gradient in an African savanna. Global Change Biology 10: 309-317. - doi: 10.1111/j.13 65-2486.2003.00696.x

Nelson DW, Sommers LE (1982). Total carbon, organic carbon, and organic matter. In: "Methods of Soil Analysis - Part 2. Chemical and Microbiological Properties" (Page AL ed). Agronomy Monograph no. 9, American Society of Agronomy and Soil Science Society of America, Madison, WI, USA, pp. 539-579.

Noh NJ, Son Y, Lee SK, Seo KW, Heo SJ, Yi MJ, Park PS, Kim RH, Son YM, Lee KH (2010). Carbon and nitrogen storage in an age-sequence of Pinus densiflora stands in Korea. Science China-Life Science 53: 822-830. - doi: 10.1007/ s11427-010-4018-0

Pan GX, Guo T (2000). Pedogenic carbonate of aridic soils in China and its significance in carbon sequestration in terrestrial systems. In: "Global Climate Changes and Pedogenic Carbonates" (Lal R, Kimble JM, Eswaran H, Stewart BA eds). Lewis, Boca Raton, FL, USA, pp. 135-148. Peichl M, Arain MA (2006). Above- and belowground ecosystem biomass and carbon pools in an age-sequence of temperate pine plantation forests. Agricultural and Forest Meteorology 140: 51-63. - doi: 10.1016/j.agrformet.2006.08. 004

Peichl M, Arain MA (2007). Allometry and partitioning of above- and belowground tree biomass in an age-sequence of white pine forests. Forest Ecology and Management 253 (1-3): 68-80. doi: $10.1016 /$ j.foreco.2007.07.003

Puigdefábregas J, Mendizábal T (1998). Perspectives on desertification: western Mediterranean. Journal of Arid Environments 39: 209-224. - doi: 10.1006/jare.1998.0401

Reynolds JF (2001). Desertification. In: "Encyclopedia of Biodiversity" (Levin S Ed). Academic Press, San Diego, CA, USA, pp. 61-78.

Pregizer KS, Euskirchen ES (2004). Carbon cycling and storage in world forests: biome patterns related to forest age. Global Change Biology 10: 1-26. - doi: 10.1111/j.1365-2486.2003.00715.x Ruiz-Peinado R, Moreno G, Juarez E, Montero G, Roig S (2013). The contribution of two common shrub species to aboveground and belowground carbon stock in Iberian dehesas. Journal of Arid Environments 91: 22-30. - doi: 10.1016/j.jarid env.2012.11.002

Schenk HJ, Jackson RB (2002). The global biogeography of roots. Ecological Monographs 72 : 311-328. - doi: 10.1890/0012-9615(2002)072 [0311:TGBOR]2.0.CO;2

Schlesinger WH, Reynolds JF, Cunningham GL,
Huenneke LF, Jarrell WM, Virginia RA, and Whitford WG (1990). Biological feedbacks in global desertification. Science 247: 1043-1048. doi: 10.1126/science.247.4946.1043

Schlesinger WH (1982). Carbon storage in the caliche of arid soils: a case study from Arizona. Soil Science 133: 247-255. - doi: 10.1097/00010 694-198204000-00008

Su Y, Wu L, Zhan Y (2012). Characteristics of carbon flux in two biologically crusted soils in the Gurbantunggut Desert, Northwestern China. Catena 96: 41-48. - doi: 10.1016/j.catena.2012. 04.003

Su YG, Li XR, Chen YW, Zhang ZS, Lu Y (2013). Carbon fixation of cyanobacterial-algal crusts after desert fixaiton and its implication to soil organic carbon accumulation in desert. Land Degradation and Development 24(4): 342-349. doi: 10.1002/ldr.1131

Suarez DL (1977). Ion activity products of calcium carbonate in waters belos the root zone. Soil Science Society of America Journal 41: 310315. - doi: 10.2136/sssaj1977.03615995004100 020027x

Taylor AR, Wang JR, Chen HYH (2007). Carbon storage in a chronosequence of red spruce (Picea rubens) forests in central Nova Scotia, Canada. Canadian journal of Forest Research 37: 22602269. - doi: 10.1139/X07-080

Tobin B, Nieuwenhuis M (2007). Biomass expansion factors for Sitka spruce (Picea sitchensis (Bong). Carr.) in Ireland. European journal of Forest Research 126: 189-196. - doi: 10.1007/s 10342-005-0105-3

Tilman D (1999). The ecological consequences of changes in biodiversity: a search for general principles. Ecology 80: 1455-1474. - doi: 10.189 0/0012-9658(1999)080[1455:TECOCI]2.0.CO;2 Tian Y, Jia Z, Yang X (2014). Improving shrub biomass estimation in the Qinghai-Tibet Plateau: Age-based Caragana intermedia allometric models. Forestry Chronicle 90 (2): 154-160.

Trumper K, Ravilious C, Dickson B (2008). Carbon in drylands: desertification, climate change and carbon finance. A UNEP-UNDP-UNCCD Technical Note for Discussions at CRIC 7, Istanbul, Turkey, pp. 1-7.

Turner DP, Koerper GJ, Harmon ME, Lee JJ (1995). A carbon budget for forests of the conterminous United States. Ecological Applications 5: 421-436. - doi: 10.2307/1942033

Verhoef A, Allen S, De Bruin HAR, Jacobs, CMnJ, Heusinkveld, BG (1996). Fluxes of carbon dioxide and water vapour from a Sahelian savanna. Agricultural and Forest Meteorology 80: 231-248. - doi: 10.1016/0168-1923(95)0229 4-5

Wang WB, Liu YD, Li DH, Hu CX, Rao BQ (2009). Feasibility of cyanobacterial inoculation for biological soil crusts formation in desert area. Soil Biology and Biochemistry 41: 926-929. doi: 10.1016/j.soilbio.2008.07.001

Whitton BA (2012). Ecology of Cyanobacteria II. Springer, Dordrecht, Heidelberg, New York, London, pp. 345-369. - doi: 10.1007/978-94-00 7-3855-3 
Woodwell GM, Machenzie FT (1995). Biotic feedbacks in the global climatic system: will the warming feed the warming? Oxford University Press, Oxford, UK, pp. 375-380. [online] URL: http://books.google.com/books?id=Tyrc32Pk5M $\mathrm{kC}$

Wu H, Guo Z, Gao Q, Peng C (2009). Distribution of soil inorganic carbon storage and its changes due to agricultural land use activity in China. Agriculture Ecosystems and Environment 129: 413-421. - doi: 10.1016/j.agee.2008.10.020 Xie ZM, Liu YD, Hu CX, Chen LZ, Li DH (2007). Relationships between the biomass of algal crusts in fields and their compressive strength. Soil Biology and Biochemistry 39 (2):
567-572. - doi: 10.1016/j.soilbio.2006.09.004 $\mathrm{Xu}$ Z, Zhou G, Wang Y (2007). Combined effects of elevated $\mathrm{CO}_{2}$ and soil drought on carbon and nitrogen allocation of the desert shrub Caragana intermedia. Plant and Soil 301 (1-2): 87-97. doi: 10.1007/s11104-007-9424-0

Yanai RD, Federer CA, Arthur MA, Siccama TG (2000). Challenges of measuring forest floor organic matter dynamics: repeated measures from a chronosequence. Forest Ecology Management 138: 273-283. - doi: 10.1016/S0378-1127(00)00 402-3

Yang L, Wu J (2010). Seven design principles for promoting scholars' participation in combating desertification. International Journal of Sustai- nable Development and World Ecology 17 (2): 109-119. - doi: 10.1080/13504500903478744 Zaady E, Kuhn U, Wilske B, Sandoval-Soto L, Kesselmeier J (2000). Patterns of $\mathrm{CO}_{2}$ exchange in biological soil crusts of successional age. Soil Biology and Biochemistry 32: 959-966. - doi: 10.1016/S0038-0717(00)00004-3

Zhang Z, Li X, Liu L, Jia R, Zhang J, Wang T (2009). Distribution, biomass, and dynamics or roots in a revegerated stand of Caragana korshinskii in the Tengger Desert, northwestern China. Journal of Plant Research 122: 109-119. doi: 10.1007/s10265-008-0196-2 